\title{
A New University in Scotland
}

\author{
by our Special Correspondent
}

ThE newest of the new universities to be created from nothing in Britain will receive its first students in September this year. The university is not English but Scottish. Its plans for academic development in the next few years are important not merely because the University of Stirling is well placed in time to profit from the lessons which have been learned in setting up other new universities in Britain, but also because those in charge, and particularly the Vice-Chancellor, Dr. T. L. Cottrell, are anxious that there should be a close integration between the teaching of science and the teaching of other material. In particular there is to be a course in technological economics intended to weld together an awareness of physical science and an awareness of the processes of applying science in industry. Although other universities in Britain are trying out

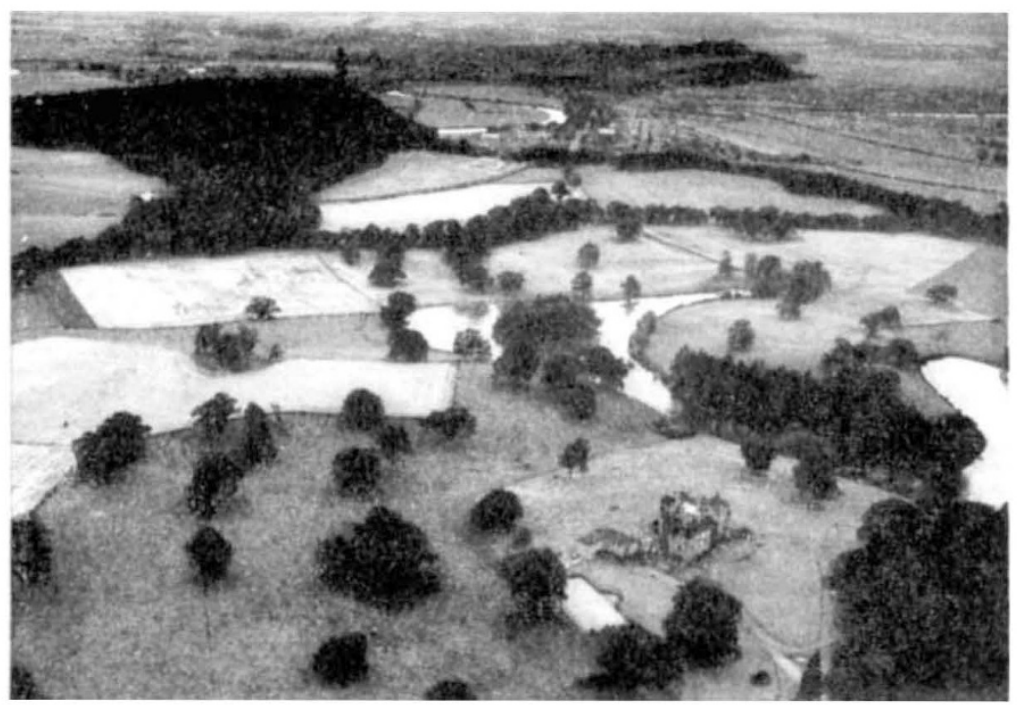
schemes to leaven the teaching of science with matter from other disciplines, particularly economics, the plans at the University of Stirling go further than those elsewhere.

The university itself plans to start in a comparatively small way, with fourteen professors (most of whom have now been appointed). The first cohort of students will number a mere 150 , plus 30 graduate students. The university is being ereated physically around a lake in a heavily wooded part of the Scottish countryside two miles north of Stirling. Fig. 1 shows the site of the university before building had begun. The university will differ from others in Britain not merely in its concern to have a course integrating science and industrial affairs but also in more general ways. For example, it is planned that the pattern of teaching shall be broken up into semesters each consisting of a 15 week period, one before and one after the winter vacation. In addition students will be required to spend at least two weeks at work in the university during the winter vacation. The result will be that if a student is to qualify for a degree, it will be possible to ask that he should have completed a certain number of semester courses.

Outwardly this means that the organization of the University of Stirling will resemble in some ways the pattern of academic life in many universities in the United States. In practice, the Vice-Chancellor intends that the contact between students and academic staff, and in particular the thoroughness of supervision, will make it possible to avoid any sense that the acquisition of seminarcourses or units will be a process comparable to the acquisition of trading stamps and other such tokens.

With luck, it is hoped that each semester course will occupy roughly the same amount of the student's time. Students will be helped to choose suitable courses by a director of studies. There will be major and subsidiary courses, the first occupying three consecutive semesters and the second two semesters. There will also be minor courses occupying merely one semester. In addition it is planned that every student shall be put through a course in "Approaches and Methods" largely concerned with the use of libraries and bibliography, communication, and what are called in the prospectus "rhetoric, logic and scientific method, statistics and social arithmetic". To complete Part I of a degree, a student will have to com. plete eight semester courses, which may for example mean

two major subjects and a subsidiary subject or-at the other extreme of diversity - one major, one subsidiary and three minor courses.

The second part of the degree course will make the total time three years for the general degree and four for the honours. The plans for technological economics are intended to cater for the education of people who may become administrators, operational researchers, or scientists working in industry. Naturally, the university provides more orthodox courses in biology, physics, chemistry and mathematics, and it will be interesting to see how great the demand is for the integrated course. Those taking the course in technological economics may begin with a school background of science specialization or may have had no science at school but only mathematics. All students following this programme will take a major course in economics in their first three semesters $(1.5$ years), two semesters of mathematics and a minor course in a subject with "introduction to techniques of industrial science" in the third semester of their stay at the university. In addition, they will follow a major course in physics, chemistry or biology or-if they have no background of science at school-in the major course "Introduction to Physical Science". The design of the Part I course is intended to enable students to switch for Part II either to a science subject or to economics if they so choose. Those wishing to continue with technological economics will finish off their degree with mathematics and statistics, a further study of economics, a continuation of their Part I science course, and special studies of industrial techniques and industrial projects.

In the planning of the course the Vice-Chancellor and his Academic Planning Board have had in mind the need somehow to train people who are skilled in science and also aware of the industrial importance of their subject. These people could go into works investigation teams, or economic planning departments in science-based industry, but there may be many other openings because, in general industry, commerce and public administration are in need of people who have a foot in each camp. But this part of the plan which the University of Stirling has designed for itself will be determined as much by circumstances, the inclinations of students, and the pedagogical innovations of the staff as by the aspirations of the planners. It is, in other words. an important and potentially illuminating experiment. 